Research Article

\title{
Health education to improve the compliance of low salt diets in patients with hypertension
}

\author{
Beti Kristinawati $^{1^{*}}$, Siti Rahmawati ${ }^{2}$, Riska Nurul Khasanah ${ }^{3}$ \\ ${ }^{1}$ Medical-Surgical Nursing, School of Nursing, Faculty of Health Sciences, Universitas \\ Muhammadiyah Surakarta, Indonesia \\ ${ }^{2,3}$ Professional Program Education, School of Nursing, Faculty of Health Sciences, \\ Universitas Muhammadiyah Surakarta, Indonesia.
}

*Correspondence: bk115@ums.ac.id. Phone: +6282137266023

\begin{abstract}
Background: The level of knowledge of hypertensive people can influence obedience in running a low-salt diet. Low levels of public awareness about low-salt diets can be at risk of complications due to hypertension and death. Health education activities in this community aim to increase the understanding of patients with hypertension on the importance of low-salt diets to improve adherence to the exercise of the diet

Methods: Educational methods used in the form of teaches and demonstrations in groups of people with hypertension in Drono village, Ngawen Sub-District, Klaten Regency.

Results: Knowledge of the hypertension diet increased between before and after educational activities. Success demonstrated with increased knowledge scores before educational activities of 3.46 and after education score rose to 85.02 .

Conclusions: Devotion to the community in health education provides increased knowledge in the group of hypertension sufferers. This activity is expected to continue, programmatic, and developed with specialized training in cadres to improve the degree of public health.
\end{abstract}

Keywords: Health education, Low salt diet, Hypertension

\section{INTRODUCTION}

Hypertension is one of the non-infectious diseases with high mortality and morbidity figures. Hypertension is a condition in which there is an increase in systolic blood pressure above 149 $\mathrm{mmHg}$ and diastolic pressure above $90 \mathrm{mmHg}$. It causes heart work to become increasingly severe in fulfilling oxygen and nutrients throughout the body (1). The World Health Organisation (WHO) in 2015 states that around 1,13 billion people in the world suffer from hypertension, with 9,4 million deaths annually (2).

Southeast Asia is an area with a hypertensive sufferer of $36 \%$ and predicted to continue to increase to $65 \%$ in 2025 (3). The prevalence of Indonesian national hypertension was 34, $1 \%(4)$. In Central Java province in the year 2016, the highest case of the non-infectious disease was hypertension, which is $61 \%$ (5). The health profile of Klaten district shows that the first sequence of the five significant not contagious diseases is hypertension. In 2018 there 


\section{Epidemiology and Society Health Review $\mid \mathbf{E S H R}$}

was an increase in the number of hypertension sufferers in Klaten District as many as 53.362 people (6).

Hypertension treatment can be conducted through two approaches: pharmacological and nonpharmacological therapy (6). The pharmacological approach through antihypertensive drugs. Non-pharmacological can be done by behavioral action: stopping smoking, avoiding alcoholic beverages, limiting salt intake, avoiding preserved and preserved food, exercising and physical activity, or doing proper self-management (7) such as restrict of salt intake (6). Low salt diet compliance in hypertensive sufferers is indispensable to achieve success in their diet therapy, thus helping to lower blood pressure and prevent complications (8). A low-salt diet in daily foods was sufficient to reduce blood pressure in patients with hypertension (9). A lowsalt diet and dietary compliance can lower systolic and diastolic blood pressure and help maintain the blood pressure of patients with hypertension (10). One factor that affects the ability to restrict salt intake is the knowledge of hypertension among the sufferers. Health education activities can enhance an individual's level of expertise.

Health education in the community is one capital to empower people and the community. The activity is not only able to improve knowledge but also can change the attitude and practice of an individual in maintaining its health independently (11). Continuing health education can lead people to participate in managing their health actively. Data from Ngawen Health Center in Drono village in 2018 recorded as many as 190 people suffering from essential hypertension (12). Our preliminary assessment of patients with hypertension in Drono village obtained 9 out of 10 sufferers have not known about the importance of low-salt diets, and the restriction of salt intake in diets consumed was also not routine. Besides, patients with hypertension still often consume instant foods high rated and foods preserved with preservatives derived from salt. Other data was found only some 40 hypertension that actively follows routine health screening activities in an integrated service post for the elderly. Research conducted by Sulistiorini about the compliance of low-salt diets in hypertensive sufferers' research locations found that people with hypertension were not obedient in choosing low-salt foods, sodiumbased herbs, and foods containing sodium preservatives (12). This study aims to understand the level of knowledge on low salt-diet compliance in hypertensive sufferers in Drono village after education. Expected with increased awareness and adherence to the exercise of the diet can help shape the positive attitude of society and improve the quality of their life.

\section{METHODS}

\section{Study design and intervention course}

The experimental, one-group pre-post-test design was applied in this study. Health education in the communities was conducted by lecture and demonstration techniques. The implementation of the activities consists of several phases: pre-test, intervention, and posttest. Three team members held the education and a demonstration on how to quantify salt consumption daily. The activity also involves a village midwife who serves as the head of health care and as a key person who provides information about the public health status of Drono village, Ngawen Sub-District, Klaten Regency.

\section{Settings and participant}

This research was conducted in Drono village, Ngawen Sub-District, Klaten Regency. The population was people with hypertension in Drono village. Data were obtained from Ngawen Public Health Center in 2018 as many as 190 patients. We took 40 samples for this research by considering purposive sampling using criteria, including people with hypertension who actively participated in the integrated service center for the elderly (Posyandu Lansia). 


\section{Epidemiology and Society Health Review $\mid \boldsymbol{E S H \boldsymbol { R }}$}

\section{Data collection and Pre and post-assessment}

Data collection was conducted in the monthly meeting of the integrated service center for the elderly (Posyandu Lansia). Pre and post-tests were delivered before and after the intervention, respectively, using similar questionnaires consisting of seven questions to measure the change of hypertension knowledge before and after the intervention (Table 2).

\section{Table 2. Inquiry List Pre and Post-Test Education}

\begin{tabular}{cl}
\hline No & Questions \\
\hline 1 & What is the purpose of the restriction of salt consumption for patients with hypertension? \\
2 & Mention a variety of low-salt diets! \\
3 & Are instant foods and foods preserved mostly high in salt content? \\
4 & What is the safe limit of salt content in instant foods and foods preserved for people \\
& with hypertension? \\
5 & How many sizes of salt consumption recommended for people with hypertension? \\
6 & How do I limit salt intake if the hypertension is eating at the restaurant? \\
7 & What is the risk if people with hypertension do not limit salt consumption? \\
\hline
\end{tabular}

\section{Analysis}

Pre and post data were administered and presented descriptively using table and chart.

\section{Ethical Approval}

The implementation of this research activity is done after the activity proposal. Memorandum of Understanding (MOU) is approved and signed by the head of Ngawen Public health center and researchers. The research team also asks for approval to respondents after being explained the intent, purpose, and permit to photograph process activities for documentation purposes by signing informed Consent.

\section{RESULTS}

Respondents were involved in this study as much as 40 people, with characteristics shown in table 1.

Table 1. Characteristics of the study subjects $(N=40)$

\begin{tabular}{llcc}
\hline \multirow{2}{*}{ Variable } & & \multicolumn{2}{c}{ Frequency } \\
\cline { 3 - 4 } & & Number & Proportion (\%) \\
\hline Gender & Male & 11 & 27.5 \\
\multirow{2}{*}{ Age (years) } & Female & 29 & 72.5 \\
& $45-59$ & 22 & 55 \\
\multirow{5}{*}{ Education } & $60-74$ & 16 & 40 \\
& $75-90$ & 2 & 5 \\
& Elementary School & 29 & 72.5 \\
& Junior High School & 7 & 17.5 \\
& Senior High School & 2 & 5 \\
& College & 2 & 5 \\
\hline
\end{tabular}


Participants' total score pre-post-test presents in Figure 1. In the pre-test, the lowest and the highest score of respondents were 28.58 and 42.87 , respectively. Subsequently, in the posttest, the respondent got a better score with the lowest score of 71.45 and the highest score of 85.74 .

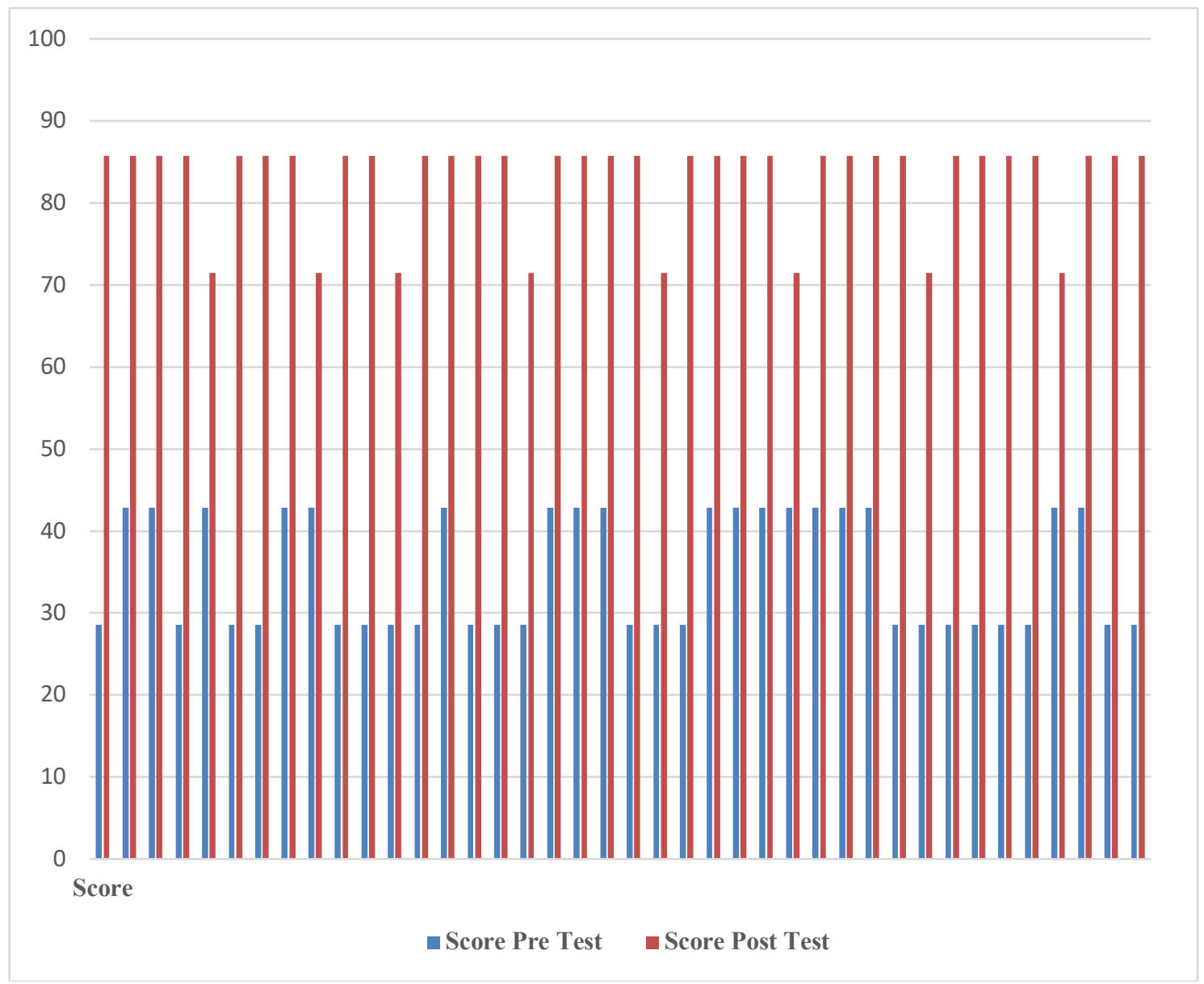

Figure 1. Total score pre and post-test for each participant

\section{DISCUSSIONS}

Non-infectious disease risk factors (NCDs) such as hypertension are categorized in a risk factor that can be modified and cannot be modified. Unmodifiable risk factors are individual characteristics that cannot be altered and cannot be controlled. These factors include age, gender, race, family history, genetics, etc. Besides, the risk factors that can be controlled are characteristics of individuals that can be adjusted or can be changed to prevent disease progression. Risk factors that can be modified Included; Obesity, high intake of salt, inactive or lack of exercise, a diet high in fat, smoking, alcohol consumption, etc. $(13,14)$.

The results of the study gained that patients with hypertension were dominated by women $(72.5 \%)$. Most sufferers (55\%) are in the $45-59$ age group. In young women, hypertension is rarely found; this condition is associated with endogenous estrogen content. Hypertension is common in women when entering the age of the elderly (65 years or more) than women $(15,16)$. Women who have entered the age of menopause are more susceptible to having 


\section{Epidemiology and Society Health Review $\mid \boldsymbol{E S H \boldsymbol { R }}$}

problems with cardiovascular one of them is hypertension because the levels of HDL patients have decreased, thereby causing atherosclerosis. Hypertension experienced by women is associated with a unique condition that is only experienced, namely related to pregnancy, menopause, and the use of oral contraceptive drugs $(16,17)$

Our result shows, based on the pre and post assessment, we found the change of knowledge among participants after the intervention. Education is part of non-pharmacological action to control blood pressure and prevent the risk of complications from hypertension (15). The possible complications for hypertension are stroke, heart attack, and kidney disease. Accordingly, proper management is required to avoid complications (14).

Education level, most elementary schools are $72.5 \%$. Low level of education affects the level of knowledge of sufferers on compliance with medication, conducting medical examinations, and maintaining a proper diet in hypertensive patients (18). Previous research obtained data that self-management by limiting salt intake to one way to control blood pressure (19). Low salt diet compliance in hypertensive sufferers is indispensable to achieve success in therapy. The knowledge assessment of a diet low in salt on research includes a variety of low-salt diets, sodium levels in the instant foods that are safe for people with hypertension, and the amount of daily sodium consumption. We also included the strategy of reducing sodium intake when eating at the restaurant as well as the purpose of limiting sodium consumption and risks that can arise when not adhered to the hypertension diet. The results of the evaluation showed that there was a significant change in educational pre-post knowledge levels.

The results of previous studies were found that there was a close connection between increasing blood pressure for hypertension and sodium intake. High sodium intake will increased blood pressure associated with the occurrence of water retention, increased peripheral resistance, changes in endothelial function, changes in structures and features of the elasticity of large blood vessels, modifications in sympathetic activity, and autonomic nerve modulation of the cardiovascular system (20).

Besides limiting salt intake, hypertensive diets limit the consumption of saturated fats and high cholesterol foods. Hypertension sufferers can use the Dietary Approaches to Stop Hypertension/DASH method in regulating food intake. DASH focuses on structuring the patient's diet with the restriction of sodium, fat, and cholesterol intake. Patients are recommended to consume a lot of foods that contain a lot of protein, calcium, potassium, and fiber to encounter the daily needs of the body (21). The study showed that the respondents' level of knowledge about the high content of sodium in low food. Healthy subjects consume fast food 3 to 4 times a week, while the fact $74 \%$ sodium content is in prepared food or fast food (22). Patients with hypertension need to reduce salt per day to a maximum of 6 grams and not more than 2400 milligrams. Patients with adherent hypertension who maintain a diet low in salt proved to lower blood pressure at 3.4 systole $\mathrm{mmHg}$ and diastolic blood pressure $1.5 \mathrm{mmHg}(23)$.

\section{CONCLUSIONS}

Education with the method of lectures and demonstrations can improve society's knowledge, especially patients with hypertension. Furthermore, increasing awareness is expected to increase adherence to low salt diets that impact the quality of life and lower the risk of complications and deaths from hypertension. Health care personnel are expected to make education a promotive and preventive effort to prevent hypertension complications. For the stakeholder, such results can be primary data to be followed up with behavioral change assessment activities in running a low-salt diet. Besides, it is expected to motivate patients 


\section{Epidemiology and Society Health Review $\mid \boldsymbol{E S H R}$}

with hypertension who have not been actively involved in activities in the integrated service center for the elderly (Posyandu Lansia) to be active. For further researchers, these results are expected to be primary data for subsequent studies.

\section{Authors' Contribution}

Each author has contributions to the process of research and the preparation of this article. $\mathrm{BK}$, as the head of the team and the speaker in education activities, RN assists in the process of research activities, and SR roled in the process of evaluating and compiling the reports of events that have conducted.

\section{Funding}

This research was funded by Universitas Muhammadiyah Surakarta, Indonesia.

\section{Conflict of Interest}

The is no conflict of interest.

\section{REFERENCES}

1. The Ministry of Health of Indonesia. Indonesian Health Profile Data and Information 2018. Jakarta: The Ministry of Health of Indonesia; 2019. Available from: https://pusdatin.kemkes.go.id/resources/download/pusdatin/profil-kesehatanindonesia/Data-dan-Informasi Profil-Kesehatan-Indonesia-2018.pdf. (in Indonesian)

2. WHO. World Health Statistic Report 2015. Geneva; 2015. https://apps.who.int/iris/bitstream/handle/10665/170250/9789240694439_eng.pdf;jsessi onid=4D55F1759CB2B1311B6315914AC5A560?sequence $=1$

3. Banik KK. Save lives: Make hospitals safe for emergencies. J Indian Med Assoc. 2009;107(4):206-7.

4. The Ministry of Health of Indonesia. Main Finding of Basic Heath Research of Indonesia (RISKESDAS) 2018. Jakarta: The Ministry of Health of Indonesia; 2019. http://kesmas.kemkes.go.id/assets/upload/dir 519d41d8cd98f00/files/Hasil-riskesdas2018 1274.pdf. (in Indonesian)

5. Klaten District Health Office. Health Profile 2018. Klaten: Klaten District Health Office. https://www.kemkes.go.id/resources/download/profil/PROFIL KAB KOTA 2018/3310 J ateng Kab Klaten 2018.pdf. (in Indonesian)

6. Ainurrafiq A, Risnah R, Ulfa Azhar M. Non-pharmacological therapy in controlling blood pressure in hypertensive patients: Systematic Review. MPPKI (Media Publ Promosi Kesehat Indones Indones J Heal Promot. 2019;2(3):192-9. (in Indonesian)

7. Burnier $M$, Vuignier $\mathrm{Y}$, Wuerzner $\mathrm{G}$. State-of-the-art treatment of hypertension: Established and new drugs. Eur Heart J. 2014;35(9):557-62.

8. Tarigan AR, Lubis Z, Syarifah $S$. The influence of knowledge, attitudes and family support for hypertension diets in Hulu Village, Pancur Batu Sub-District in 2016. J Kesehat. 2018;11(1):9-17. (in Indonesian)

9. Kiha RR, Palimbong S, Kurniasari MD. The effectiveness of a low-salt diet in ordinary and soft foods for the duration of recovery of hypertensive patients. J Keperawatan Muhammadiyah. 2018;3(1). (in Indonesian) 


\section{Epidemiology and Society Health Review $\mid \boldsymbol{E S H \boldsymbol { R }}$}

10. Hayati A. Evaluation of Treatment Compliance among Patients with Lung Tuberculosis year 2010-2011 in Pancoran Mas Health Center, Depok. Universitas Indonesia; 2011. (in Indonesian)

11. Bisallah Cl, Rampal L, Lye MS, Sidik SM, Ibrahim N, lliyasu Z, et al. Effectiveness of health education intervention in improving knowledge, attitude, and practices regarding Tuberculosis among HIV patients in General Hospital Minna, Nigeria - A randomized control trial. PLoS One. 2018;13(2):1-14.

12. Sulistiorini H. Kepatuhan Diet Rendah Garam Pada Penderita. Universitas Muhammadiyah Surakarta; 2019. (in Indonesian)

13. Mayega RW, Makumbi F, Rutebemberwa E, Peterson S, Östenson CG, Tomson G, et al. Modifiable socio-behavioural factors associated with overweight and hypertension among persons aged 35 to 60 years in Eastern Uganda. PLoS One. 2012;7(10).

14. Ahmed N, Rahman M, Islam M, Ali S, Hossain A, Fatema K, et al. Socio-demographic, clinical characteristics and status of hypertension control among rural hypertensive patients. Faridpur Med Coll J. 1970;6(1):5-9.

15. Nuraini B. Risk factors of hypertension. J Major. 2015;4(5):10-9.

16. Ahmad A, Oparil S. Hypertension in women: recent advances and lingering questions. Hypertension. 2017;70(1):19-26.

17. Rahmatika $D$. The relationship between emotional support and adherence to the diet of elderly people with hypertension. The Indonesian Journal of Public Health. 2019; 14(2):252-262. (in Indonesian)

18. Pramestutie HR, Silviana N. The knowledge level of hypertension patients for drug therapy in the primary health care of Malang. Indones J Clin Pharm. 2016;5(1):26-34.

19. Welviana I, Waliyo E. General description of food scraps and nutritional status in hypertensive patients who receive a low salt diet at Sultan Syarif Mohamad Alkadrie Hospital Pontianak. Pontianak Nutr J. 2018;1(1):40. (in Indonesian)

20. Grillo A, Salvi L, Coruzzi P, Salvi P, Parati G. Sodium intake and hypertension. Nutrients. 2019;11(9):1-16.

21. Apriana R, Rohana N, Simorangkir Y. The relationship between the application of the DASH (Dietary Approach to Stop Hypertension) method with the level of hypertension. Medisains. 2017;15(3):179-84. (in Indonesian)

22. Prihatini S, Permaesih D, Julianti ED. Sodium intake of Indonesians: Analysis of 2014 individual food consumption survey (SKMI) data. Gizi Indones. 2017;39(1):15. (in Indonesian)

23. Fauziah NY, Bintanah S, Handarsari E. The pattern of consumption of sodium food ingredients in outpatient hypertension patients at Tugurejo Hospital Semarang. J Gizi Univ Muhammadiyah Semarang. 2013;2(1):1-9. (in Indonesian) 
Epidemiology and Society Health Review $\mid \boldsymbol{E S H R}$ 